\title{
Kidney injury in response to crystallization of calcium oxalate leads to rearrangement of the intrarenal T cell receptor delta immune repertoire
}

\author{
Chao Zhu ${ }^{1 \dagger}$, Qing Liang ${ }^{2 \dagger}$, Yaqun Liu ${ }^{3 \dagger}$, Deliang Kong ${ }^{1}$, Jie Zhang ${ }^{1}$, Hu Wang ${ }^{1}$, Kejia Wang ${ }^{2^{*}}$ and Zhiyong Guo ${ }^{\text {* }^{*}}$
}

\begin{abstract}
Background: Calcium oxalate ( $\mathrm{CaOx}$ ), the major constituent of most kidney stones, induces inflammatory infiltration and injures renal tubular cells. However, the role of $\gamma \delta T$ cells in $\mathrm{CaOx}$-mediated kidney injury remains unclear. Therefore, this study investigated the distribution of intrarenal $\gamma \delta$ T cells and T cell receptor $\delta(T C R \delta)$ immune repertoires in response to interactions with $\mathrm{CaOx}$ crystals.

Methods: CaOx crystal mouse model was established by glyoxylate injection. Flow cytometer was used to analyze the expression of CD69 and IL-17 from intrarenal $\gamma \delta T$ cells. Furthermore, TCR immune repertoire sequencing (IR-Seq) was used to monitor the profile of the TCR $\delta$ immune repertoire.

Results: Our results indicated that $\mathrm{CaOx}$ crystals lead to obvious increases in the expression and activation of intrarenal $\gamma \delta T$ cells. In TCR $\delta$ immune repertoire, the majority of $V / J$ gene and $V-J / N-D-J$ combination segments, barring individual exceptions, were similar between kidneys with CaOx formation and control kidneys. Impressively, high complementarity determining region 3 (CDR3) diversity was observed in response to CaOx crystal formation along with distinct CDR3 distribution and abundance.
\end{abstract}

Conclusion: Our work suggests the presence of aberrant $\gamma \delta T$ cell activation and reconstitution of the TCR $\delta$ immune repertoire in response to CaOx crystal deposition.

Keywords: T cell receptor, Immune repertoire, $§ \delta T$ cell, Calcium oxalate, Kidney stone

\section{Background}

Kidney stones, which primarily settle in the kidneys, are the most common disorder of the urinary tract, and their worldwide prevalence has increased over the decades [1]. The estimated prevalence of kidney stones in China is 650 per 10,000 people [2]. The most common renal stone component is $\mathrm{CaOx}$, accounting for $65.9 \%$ of all stones. Hyperoxaluria is one of the primary risk factors

\footnotetext{
*Correspondence: wangkejia@xmu.edu.cn; drguozhiyong@163.com ${ }^{\dagger}$ Chao Zhu, Qing Liang and Yaqun Liu contributed equally to this work ${ }^{1}$ Department of Nephrology, Changhai Hospital, Second Military Medical University, Shanghai 200433, China

${ }^{2}$ Department of Basic Medical Sciences, School of Medicine, Xiamen University, Xiamen 361102, Fujian, China

Full list of author information is available at the end of the article
}

for the occurrence of $\mathrm{CaOx}$ crystals, which may be influenced by a vegetarian diet and high carbohydrate intake [3]. Currently, it is widely accepted that kidney stones are a systemic disorder associated with an increased risk of chronic kidney diseases, renal cancer, metabolic disorder, renal failure, and cardiovascular diseases [4-7]. Kidney stones have become a serious problem in human health, and an appropriate prevention strategy is urgently needed.

$\gamma \delta \mathrm{T}$ cells, consisting of a gamma $(\gamma)$ and delta $(\delta) \mathrm{T}$ cell receptor (TCR) chain, are primarily $\mathrm{CD} 4^{-} / \mathrm{CD} 8^{-}$ negative $\mathrm{T}$ cells. Although $\gamma \delta \mathrm{T}$ cells normally account for $1-10 \%$ of circulating $\mathrm{T}$ lymphocytes, they constitute the major subset of resident $\mathrm{T}$ cells in the mucosa and organs $[8,9]$. Unlike $\alpha \beta$ T cells, $\gamma \delta$ T cells primarily

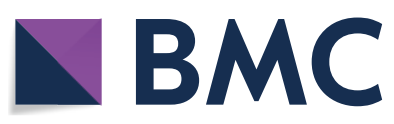

(c) The Author(s) 2019. This article is distributed under the terms of the Creative Commons Attribution 4.0 International License (http://creativecommons.org/licenses/by/4.0/), which permits unrestricted use, distribution, and reproduction in any medium, provided you give appropriate credit to the original author(s) and the source, provide a link to the Creative Commons license, and indicate if changes were made. The Creative Commons Public Domain Dedication waiver (http://creativecommons.org/ publicdomain/zero/1.0/) applies to the data made available in this article, unless otherwise stated. 
sense early environmental stimuli, independent of an interaction with the major histocompatibility complex (MHC) on antigen-presenting cells (APCs), to mediate immunosurveillance and immunoregulation [10-12]. Therefore, $\gamma \delta \mathrm{T}$ cells are characteristic of the adoptive immune compartment with innate-like response reactions. In inflammatory-mediated kidney injury, a variety of T cells ( $\gamma \delta \mathrm{T}$ cells, NKT cells, regulatory T cells) infiltrate the kidney, and the number and subset composition of infiltrating $\mathrm{T}$ cells varies among the different forms of kidney injury [13].

Emerging studies indicate that $\mathrm{CaOx}$ crystals boost the secretion of reactive oxygen species (ROS), proinflammatory cytokines, chemokines, and fibrotic factors, which aggravate renal interstitial inflammation in kidney stones [14-16]. In addition, there is evidence that these chemokines and cytokines subsequently enhance the recruitment of various immunocytes, including monocytes, macrophages, neutrophils, and $\mathrm{T}$ cells, to the $\mathrm{CaOx}$-mediated inflammatory locale [17]. Nevertheless, the interaction between $\mathrm{CaOx}$ crystals and $\gamma \delta \mathrm{T}$ cells and whether exposure to $\mathrm{CaOx}$ crystals induces alterations in $\gamma \delta \mathrm{T}$ cell distribution and activation remain unknown.

Based on a preceding study, we deduced that IRSeq represents a potential strategy for monitoring the immune microenvironment $[18,19]$. In this study, we measured the quantity and activity of $\gamma \delta \mathrm{T}$ cells in kidneys with $\mathrm{CaOx}$ formation, and TCR IR-Seq was used to monitor the expression pattern and clonality of the TCR repertoire in intrarenal $\gamma \delta \mathrm{T}$ cells. Analysis of the TCR $\delta$ immune repertoires can improve our basic understanding of $\gamma \delta \mathrm{T}$ cell immunology in renal stone disorders.

\section{Methods}

\section{CaOx crystal mouse model}

Wild-type male C57BL/6 mice (8-10 weeks old) were purchased from Daren Fortune Animal Technology Co., Ltd. (Qingdao, Shandong, China) and were maintained in the SPF barrier facility animal rooms under a controlled 12-h light/dark cycle at $20-25{ }^{\circ} \mathrm{C}$ with $55-56 \%$ relative humidity. All procedures were approved by the Second Military Medical University of the Medicine Institutional Animal Care and Use Committee. The $\mathrm{CaOx}$ crystal renal injury mouse model was established as previously described [20]. Briefly, mice were intraperitoneally (i.p.) injected with glyoxylate (Sigma-Aldrich, St. Louis, MO) at a dosage of $100 \mathrm{mg} / \mathrm{kg}$ or $0.9 \%$ saline once daily. After 7 days, kidneys were harvested. The left kidney was used for $\mathrm{T}$ cell isolation, and the right kidney was fixed in $4 \%$ paraformaldehyde for histological analysis.

\section{Histological analysis}

Right kidney specimens were paraffin-embedded and sectioned at a thickness of $5 \mu \mathrm{m}$. Then, sections were deparaffinised, hydrated, and stained using a von Kossa Kit (Jiemei Gene, Shanghai, China) followed by subsequent Eosin counterstaining (Beyotime Institute of Biotechnology, Jiangsu, China). $\mathrm{CaOx}$ crystal deposition was assessed by 2 experienced pathologists using microscopy (Nikon Eclipse 50i; Nikon Corporation, Tokyo, Japan). Deposition scores were assigned as follows: (1) no deposition $=0$; (2) deposition in the papillary tip $=1$; (3) deposition in the corticomedullary junction $=2$; (4) deposition in the cortex $=3$.

Immunohistochemical staining was performed as previously described using a commercial immunohistochemical kit (SA1020, Boster, Hubei, China) [21]. Slides were incubated with primary antibodies against $\mathrm{TCR} \gamma \delta$ (GL3, 1:200, Abcam) overnight at $4{ }^{\circ} \mathrm{C}$ followed by incubation with secondary antibodies (Santa Cruz Biotechnology). Staining intensity was assessed using Image-Pro Plus 6.0 software (Media Cybernetics, MD, USA).

\section{T cell isolation and flow cytometry analysis}

$\mathrm{T}$ cell isolation was performed as previously described. Briefly, a small incision was made in the portal vein, and a gauge needle was carefully inserted into the left ventricle of the heart to flush PBS through the cardiovascular system. Then, kidneys were mechanically disrupted into small pieces and transferred into digestion buffer [RPMI 1640 medium with $10 \mathrm{mg} / \mathrm{mL}$ Type 1 collagenase, $10 \mathrm{mg} /$ $\mathrm{mL}$ DNAse, $10 \%$ foetal calf serum (FCS)] at $37{ }^{\circ} \mathrm{C}$ for 30 min. Next, $1 \mathrm{~mL}$ RPMI 1640 medium with 2\% FCS was added to the suspension to stop digestion followed by filtration through a $100 \mathrm{~mm}$ nylon mesh to remove any remaining tissue fragments. When permeabilization was required, cells were incubated with $0.5 \%$ Triton X-100 (Solarbio, Beijing, China) for $10 \mathrm{~min}$ after fixation by $4 \%$ paraformaldehyde at room temperature. For $\gamma \delta \mathrm{T}$ cell detection, cells were washed, and then stained using antibodies directed against mouse $\mathrm{TCR} \gamma \delta$ (Biolegend, Beijing, China), IL-17 (Biolegend) and CD69 (Biolegend) for $20 \mathrm{~min}$ at room temperature in the dark. BD Accuri C6 (BD Biosciences, Mountain View, CA, USA) was used to obtain and analyse the data.

\section{RNA extraction and TCR repertoires library preparation}

Total RNA from $\gamma \delta \mathrm{T}$ cells was extracted using the RNAprep Pure Cell/Bacteria Kit (Tiangen Biotech, Beijing, China). Quality and quantity of RNA were assessed using a NanoDrop spectrophotometer (Thermo Fisher Scientific, USA). Next, 200 ng RNA was utilized for reverse transcription using First-strand, and cDNA was 
synthesized using a Transcriptor First Strand cDNA Synthesis Kit (Roche Applied Science, Penzberg, Germany) according to the manufacturer's protocol on a T100TM Thermal Cycler (Bio-Rad Inc., CA, USA).

\section{TCR $\delta$ repertoire preparation and IR-Seq}

The TCR $\delta$ immune repertoire was amplified by tworound multiplex PCR using specific primers designed for TCR $\delta \mathrm{V}$ and $\mathrm{C}$ regions according to the international ImMunoGene Tics information system (IMGT, http:// www.imgt.org/). IR-Seq and data analysis were performed as previously described [19].

\section{Statistical analysis}

Data are presented as the mean \pm standard deviation. Statistical significance was determined using a 2-tailed, unpaired Student's t-test or Mann-Whitney U test. Significance was accepted at $P<0.05$. Heatmaps, volcano plots and principal component analysis (PCA) plots were generated using R software (version 3.5.1).

\section{Results}

CaOx-mediated kidney injury activates intrarenal $\gamma \delta T$ cells Haematoxylin and eosin (HE) and von Kossa staining revealed that glyoxylate induced the deposition of $\mathrm{CaOx}$ crystals in kidneys (Fig. 1a). To investigate the distribution of intrarenal $\gamma \delta \mathrm{T}$ cells in response to $\mathrm{CaOx}$, we labelled $\gamma \delta \mathrm{T}$ cells by immunohistochemistry. The results indicated higher levels of intrarenal $\gamma \delta \mathrm{T}$ cells in $\mathrm{CaOx}$ mediated kidney injury compared to healthy kidneys (Fig. 1b). Furthermore, we examined the expression and activation of $\gamma \delta \mathrm{T}$ cells by flow cytometry analysis. As expected, $\mathrm{CaOx}$ induced an obvious increase in the percentage of $\gamma \delta \mathrm{T}$ cells, along with enhanced CD69 and IL-17 levels compared to controls, indicating significant activation of $\gamma \delta \mathrm{T}$ cells in $\mathrm{CaOx}$-induced kidneys (Fig. 1c, d).

\section{Profiling of $V, D$ and J segment usage by $\gamma \delta T$ cells in CaOx-induced kidney injury}

To explore the distribution and expression of $\gamma \delta \mathrm{T}$ cells in response to $\mathrm{CaOx}$ crystal deposition, we assessed the intrarenal immune repertoire by IR-seq. This analysis yielded $1.26 \times 10^{7}$ to $2.19 \times 10^{7}$ reads per sample in raw data. V and J segments were identified using BLAST Plus software based on the IMGT database. Thirteen distinct $\mathrm{V}$ gene segments and 2 distinct $J$ segments were observed from all samples, and there were few differences in $\mathrm{V} / \mathrm{J}$ clonotypes between the two groups (Additional file 1: Dataset S1). Interestingly, the use of $\mathrm{V}$ and $\mathrm{J}$ segments

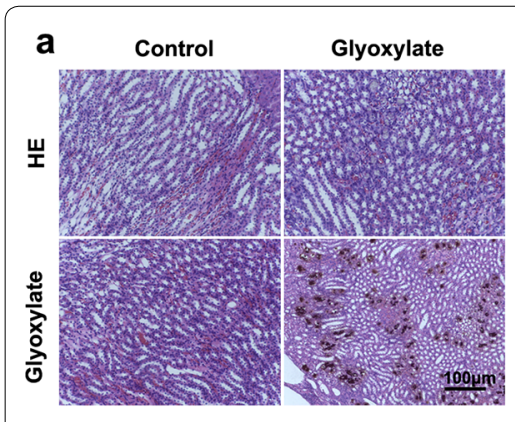

C

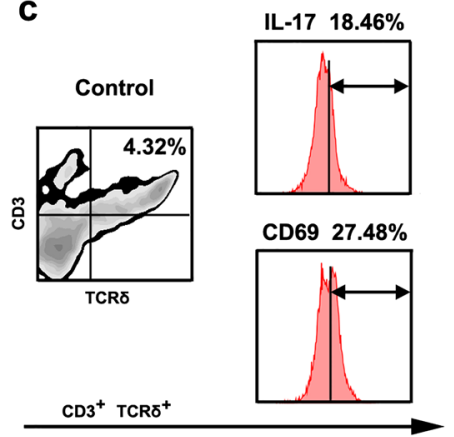

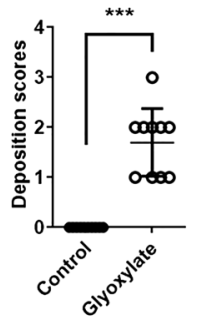

b
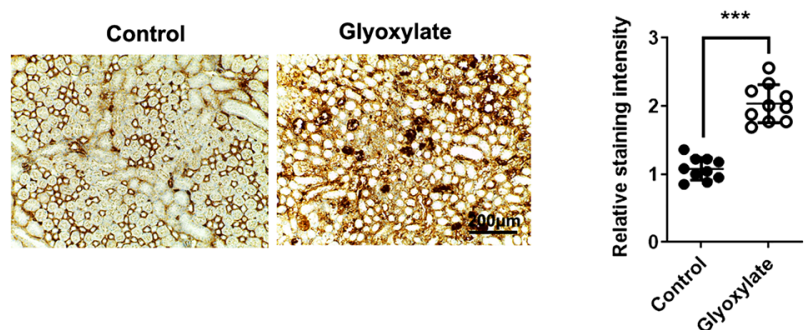

Fig. 1 CaOx crystals activate $\gamma \delta T$ cells in the kidney. Ten mice were intraperitoneally injected with glyoxylate at 100 mg/kg or $0.9 \%$ saline once daily for 7 days. a HE and von Kossa staining was performed in mouse kidneys. Deposition scores were measured. $\mathbf{b}$ Immunohistochemical staining of TCRy $\delta$ in kidneys. The staining intensity of TCRy $\delta$ was calculated in 10 high power microscopic fields. c $\gamma \delta \mathrm{T}^{\left(C D 3^{+}\right.}$, TCR $\left.\gamma \delta^{+}\right)$cells were gated and tested for the expression of CD69/IL-17 by flow cytometry. $\mathbf{d}$ The percentage of $\gamma \delta T$ cells and the expression of CD69 and IL-17 gated from $\gamma \delta T$ cells were quantified by flow cytometry (10 mice per group). ${ }^{*} P<0.05 ;{ }^{* *} P<0.01 ;{ }^{* * *} P<0.001$ 
was dominated by high-frequency clonotypes in both glyoxylate and control groups (Fig. 2a, b). Comparison of $\mathrm{V}$ and $\mathrm{J}$ frequencies revealed that the majority of $\mathrm{V}$ and $\mathrm{J}$ segment usage was similar (Fig. 2c). Only the frequency of TRDV4 was upregulated in the glyoxylate group compared to the control group (Fig. 2d).

In addition, we determined the composition of paired $\mathrm{V}-\mathrm{J}$ combinations and paired $\mathrm{V}-\mathrm{D}-\mathrm{J}$ combinations. There were a total of $22 \mathrm{~V}-\mathrm{J}$ combinations and $93 \mathrm{~V}-\mathrm{D}-\mathrm{J}$ combinations (Additional file 2: Dataset S2). Of note, $\mathrm{CaOx}$ crystals led to diversified clonotypes of $\mathrm{V}-\mathrm{J}$ and V-D-J combinations (Fig. 3a, b). Volcano plots were generated according to the frequency of $\mathrm{V}-\mathrm{J}$ and $\mathrm{V}-\mathrm{D}-\mathrm{J}$ combinations (Fig. 3c). Similar to the use of V and J segments, the frequency of most $\mathrm{V}-\mathrm{J}$ and $\mathrm{V}-\mathrm{D}-\mathrm{J}$ combinations was not different between the two groups. Only the frequencies of TRDV4/TRDJ2, TRDV4/TRDD2/TRDJ2 and TRDV7/TRDD2/TRDJ1 were increased in $\mathrm{CaOx}$ induced damaged kidneys (Fig. 3d).

\section{CaOx crystals lead to a resetting of the TCR $\delta$ CDR3 clonotypes}

CDR3, the most abundant region in the TCR repertoire, indicates the diversity of the TCR repertoire. In the current study, 79,307 distinct CDR3 clonotypes of
TCR $\delta$ were identified (Additional file 3: Dataset S3). Of note, $\mathrm{CaOx}$ crystals led to remarkable increases in CDR3 TCR $\delta$ clonotypes (Fig. 4a). Interestingly, shared CDR3 clonotypes of samples among different groups were substantially lower than those in the same group, indicating reconstitution of TCR $\delta$ CDR3 clonotypes during $\mathrm{CaOx}$ crystal deposition (Fig. 4b). Moreover, rank-abundance analysis and the Simpson index suggested increased diversity of CDR3 clonotypes in CaOx-induced kidney injury (Fig. 4c, d).

A heatmap of CDR3 clonotype expression was generated by cluster analysis based on usage patterns. In accordance with CDR3 AA diversity, $\mathrm{CaOx}$ crystals diversified usage patterns of CDR3 clonotypes (Fig. 4e). Furthermore, we compared the frequency of CDR3 clonotypes between the two groups, identifying 19 downregulated CDR3 clonotypes and 8 upregulated CDR3 clonotypes (Table 1 and Fig. 4f). As shown by the PCA plot, the glyoxylate group exhibits centralized distribution, suggesting that the composition of CDR3 clonotypes in the glyoxylate group is clearly distinct from the control group (Fig. 4g). However, there were no significant differences observed in CDR3 AA usage or CDR3 AA length between the two groups (Additional file 4: Figures S1, S2).

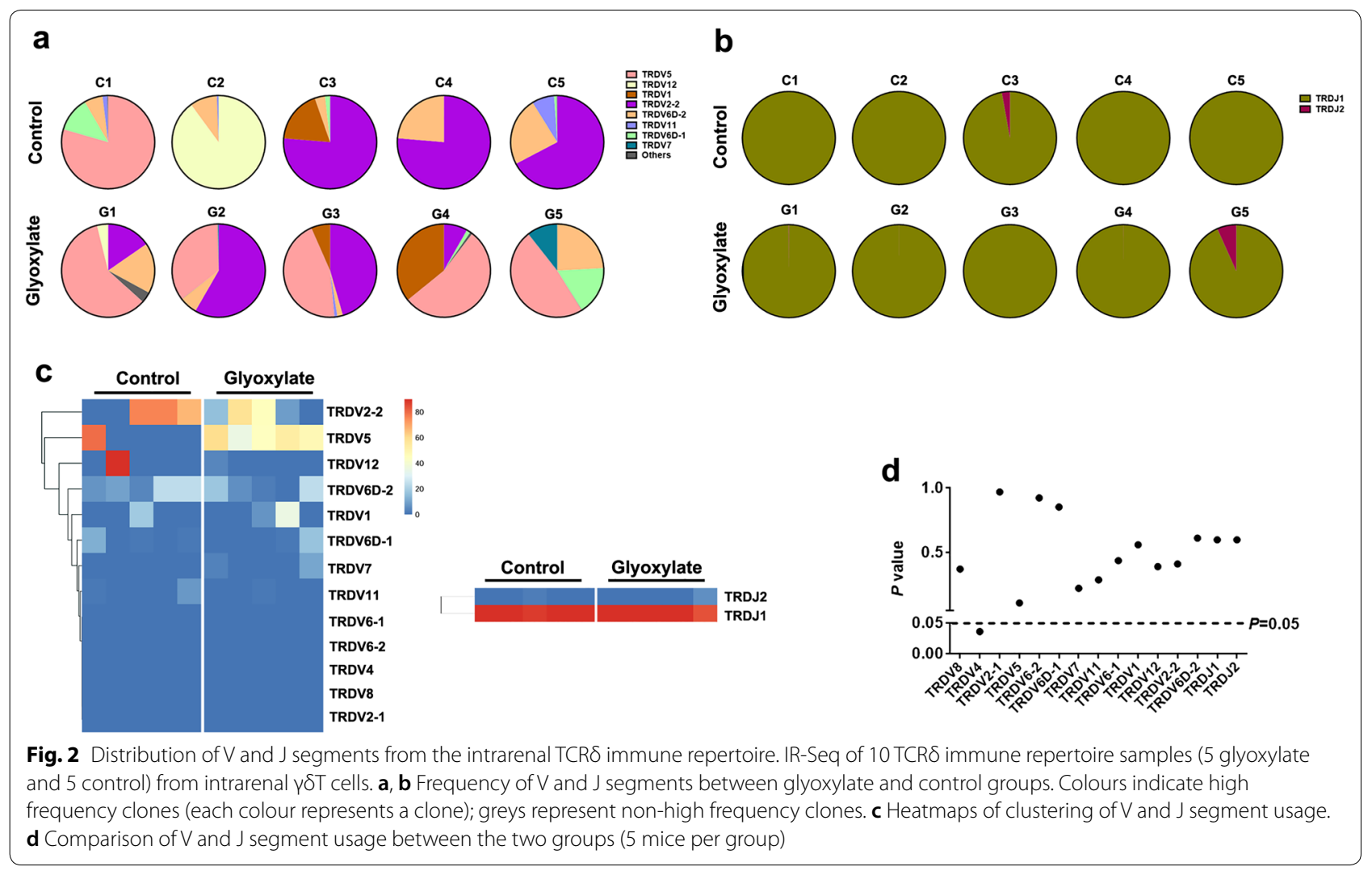




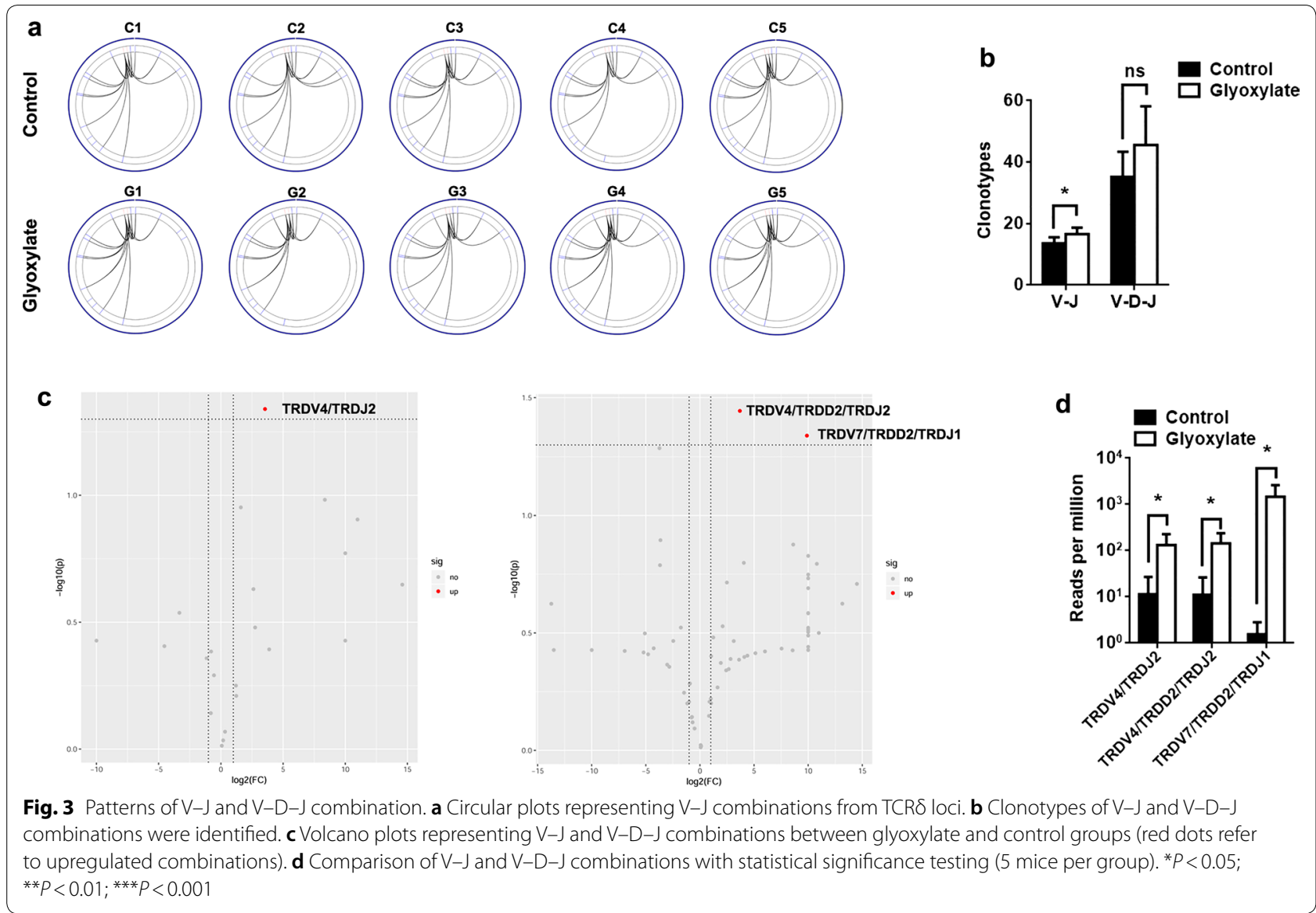

\section{Discussion}

$\mathrm{T}$ cells play a critical role in immune-mediated kidney disorders, including glomerulonephritis, ischaemia-reperfusion injury, and renal fibrosis [22-24]. Accumulating evidence suggests that $\mathrm{T}$ cells act as helper cells for cytotoxic $\mathrm{T}$ cell production, for macrophage recruitment or as effector cells within kidneys by cytokine production, affecting immune function [25]. T cell dysfunction often causes acute and chronic inflammation that impairs renal function. Despite leukocyte infiltration after renal obstruction, far less is known about $\mathrm{T}$ cell distribution and function [24]. Nevertheless, there is clear evidence that $\gamma \delta \mathrm{T}$ cells are essential for kidney injury [26]. Deficiencies in $\gamma \delta \mathrm{T}$ cells cause minimal renal lesions and obviously reduced recruitment of other immunocytes [27].

$\gamma \delta \mathrm{T}$ cells are involved in elimination of various pathogens, inflammation control and maintenance of tolerance via specific recognition using TCR [28]. Interestingly, $\gamma \delta \mathrm{T}$ cells can also initiate adaptive effector functions without MHC restriction, suggesting direct presentation similar to that of antigen-presenting cells $[8,29]$. In addition, the composition of $\gamma \delta \mathrm{T}$ cells exhibits apparent imparity in diverse tissues. Therefore, the mechanisms of $\gamma \delta \mathrm{T}$ cells in pathology are difficult to identify. Previous studies indicate that $\gamma \delta \mathrm{T}$ cells mediate inflammatory cell infiltration (cytotoxic $\mathrm{T}$ cells and neutrophils) through IL-17A production, which contributes to pathogenesis and accelerates kidney injury $[24,27]$. However, the role of $\gamma \delta \mathrm{T}$ cells in $\mathrm{CaOx}$-meditated renal injury is still unclear. A recent study suggested that $\gamma \delta \mathrm{T}$ cells, especially IL-17A producing $\gamma \delta \mathrm{T}$ cells, accumulate following unilateral ureteral obstruction-induced renal injury [24]. Consistent with previous studies, our results revealed elevated percentages and enhanced activation of $\gamma \delta \mathrm{T}$ cells in kidneys in response to $\mathrm{CaOx}$ crystal deposition, implying a crucial role for $\gamma \delta \mathrm{T}$ cells in $\mathrm{CaOx}$ crystal-mediated renal injury.

Emerging evidence demonstrates that endogenous and exogenous stimuli lead to TCR immune repertoire rearrangement, facilitating antigen recognition of TCR [30-32]. Indeed, enhanced activation of $\gamma \delta \mathrm{T}$ cells can be attributed to $\mathrm{CaOx}$ crystals and $\mathrm{CaOx}$ crystal-mediated renal injury. Nevertheless, the profile of the TCR $\delta$ immune repertoire during the process of $\mathrm{CaOx}$ crystal deposition is not clear. Our preceding studies propose that TCR acts as a "commander" to monitor the immune 


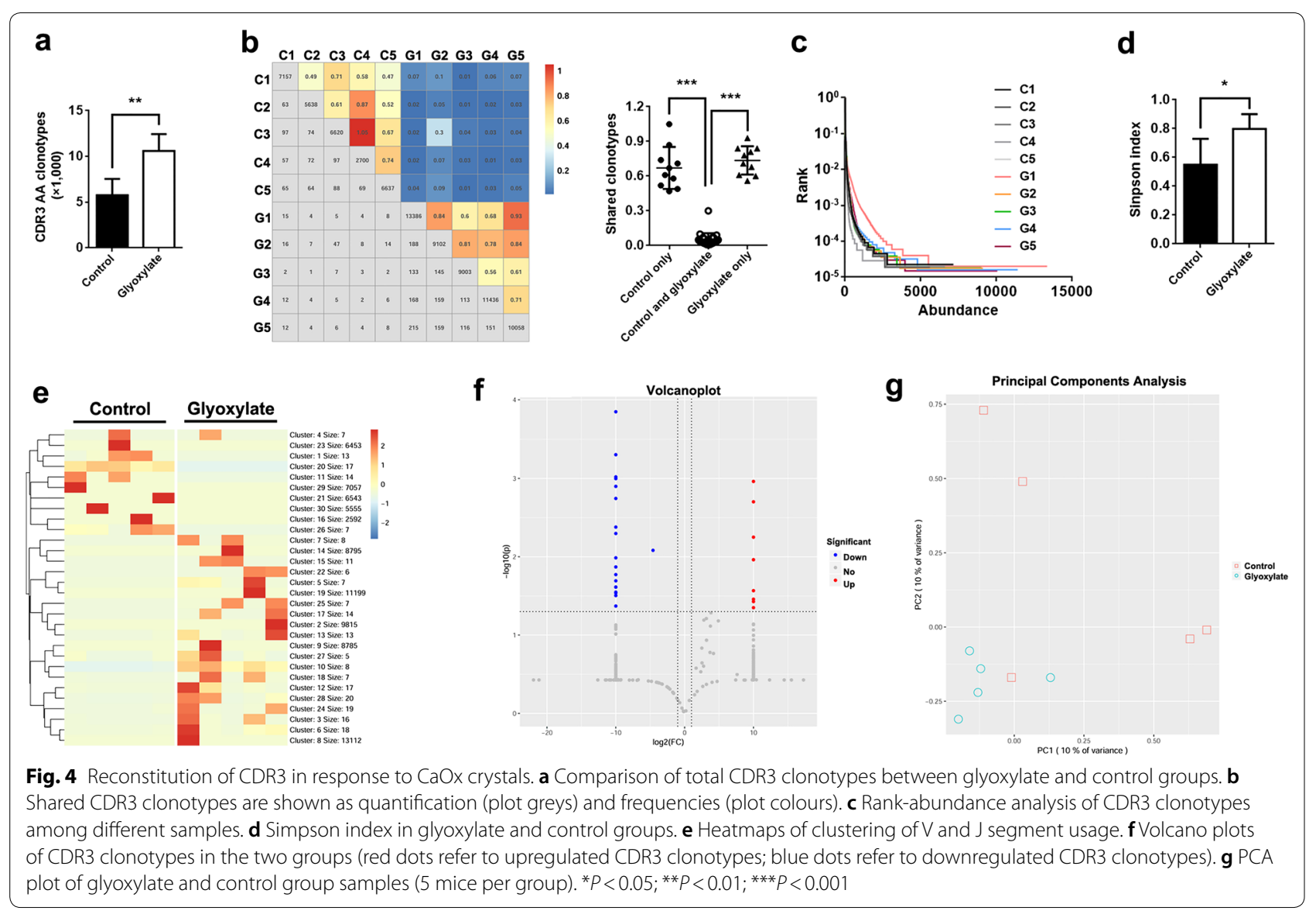

microenvironment and allocate immunocytes for immune elimination and immune repair [33]. Currently, TCR is understood to be one of the pathophysiological mediators in kidney ischaemia-reperfusion injury, and identification of TCR function in the kidney could also be conducive to identifying new therapies for renal injury [23]. Therefore, identifying and tracking TCR immune repertoires provides a novel strategy for understanding the mechanism of $\mathrm{T}$ cells in renal injury.

In this study, characteristics of $\mathrm{V}, \mathrm{D}, \mathrm{J}$ and CDR3 usage patterns were measured using IR-seq. Of note, a more centralized distribution of $\mathrm{V}$ and $\mathrm{J}$ segments was identified in both glyoxylate and control groups. Our results coincide with previous findings that the TCR V region repertoire in particular is highly tissue specific, with $75 \%$ of peripheral blood $\gamma \delta \mathrm{T}$ cells expressing TRDV2 [34]. Interestingly, the proportion of $\gamma \delta \mathrm{T}$ cells expressing TRDV5 increased in response to $\mathrm{CaOx}$ crystal deposition but did not reach statistical significance. Although the majority of $\mathrm{V}, \mathrm{J}, \mathrm{V}-\mathrm{J}$ and $\mathrm{V}-\mathrm{D}-\mathrm{J}$ combination usage were similar, $\mathrm{CaOx}$ crystal deposition induced diversification of the clonotypes of V-J and V-D-J combinations. Moreover, obviously elevated CDR3 clonotypes and variance were observed in the glyoxylate group, suggesting that $\mathrm{CaOx}$ crystal deposition leads to enhanced TCR $\beta$ diversity and VDJ recomposition. These data support that TCR immune repertoire rearrangement occurs to facilitate the recognition of renal autoantigens, which induces $\gamma \delta \mathrm{T}$ cell activation and kidney injury. Meanwhile, chemokines and cytokines recruit other immunocytes synergistically with $\gamma \delta \mathrm{T}$ cells to promote renal inflammation.

Indeed, the TCR $\delta$ immune repertoire exhibits traits of the immune microenvironment in kidneys in response to $\mathrm{CaOx}$ crystal deposition, thus improving our understanding of the role of $\gamma \delta \mathrm{T}$ cells in renal injury in response to $\mathrm{CaOx}$ crystal deposition. Interestingly, our ongoing work also finds the rearrangement of the intrarenal TCR $\beta$ immune repertoire during renal ischemia reperfusion injury, which demonstrates that TCR reconstitution may be a common occurrence in kidney diseases. However, the relationship between the TCR reconstitution and TCR signalling pathway or biological effect (including $\mathrm{T}$ cell activation) are still not clear. Unfortunately, the biological effect of TCR $\delta$ immune repertoire reconstitution is still unknown. In future studies, the mechanism 
Table 1 Analysis of CDR3 AA clonotypes in response to kidney injury by $\mathrm{CaOx}$

\begin{tabular}{lll}
\hline CDR3 AA clonotypes & p value & Significant \\
\hline ASGIWQISEGYELTDKL & 0.0135 & Down \\
AVYHCILRLIGGIRATDKL & 0.0426 & Down \\
AICGIHILLSEGYGTDKL & 0.0243 & Down \\
ALSELIVDKL & 0.0083 & Down \\
ASGYVAWGYRRVATDKL & 0.0010 & Down \\
ASGYMTSEGYELSDKL & 0.0013 & Down \\
ASGSMREDTDKL & 0.0010 & Down \\
ASGLIWPTEGYELTDKL & 0.0001 & Down \\
ALMEREGRRDTTDKL & 0.0042 & Down \\
ASQPSHSGTYLCGGKAGIRATDKL & 0.0103 & Down \\
ASGSTYRRDTYGATDKL & 0.0313 & Down \\
AVYHCILRLIWPIGGISTDKL & 0.0244 & Down \\
ASGLIWPTEGHELTDKL & 0.0169 & Down \\
ALMERARRDTHKL & 0.0203 & Down \\
ALSEVPSEGYAAPDKL & 0.0283 & Down \\
AVYHCILRGYGISEGSTDKL & 0.0050 & Down \\
ALMEQGGIRATDKL & 0.0005 & Down \\
ASQPSHSGTYLCGGGRGRYRRDTSSATDKL & 0.0018 & Down \\
ALWELAAEGYELSDKL & 0.0290 & Down \\
ATYYCGSDIGGSSWDTRQMSFGTGIEL & 0.0348 & Up \\
ARRAGGIRATDKL & 0.0271 & Up \\
ALMDRRVPATDKL & 0.0056 & Up \\
ASGAYIGGIRATDKL & 0.0447 & Up \\
ASGAYIGGIRTTDKL & 0.0011 & Up \\
AGMYYCGSDIGGSSWDTRQMF & 0.0373 & Up \\
ALSKLDMAYIGGIRATDKL & 0.0109 & Up \\
ALSELIGGIRATDKL & 0.0020 & Up \\
\hline & & \\
\hline
\end{tabular}

and signalling pathways that associate with the TCR $\delta$ immune repertoire will be assessed.

\section{Conclusion}

The present study demonstrates that $\mathrm{CaOx}$ crystal deposition causes $\gamma \delta \mathrm{T}$ cell accumulation and activation. Further IR-seq of TCR $\delta$ elucidated anomalous TCR $\delta$ immune repertoire diversity. Transformation of the TCR immune repertoire might be therapeutically exploited in kidney injury in the future.

\section{Supplementary information}

Supplementary information accompanies this paper at https://doi. org/10.1186/s12967-019-2022-0.

Additional file 1. Comparison of TRDV and TRDJ usage.

Additional file 2. Comparison of $\mathrm{V}-\mathrm{J}$ and $\mathrm{V}-\mathrm{D}-\mathrm{J}$ usage.

Additional file 3. Comparison of CDR3 AA usage.
Additional file 4: Figure S1. Distribution of CDR3 AA length in the TCR immune repertoire between glyoxylate and control groups. Figure S2. Comparison of the fraction of CDR3 AA between glyoxylate and control groups.

\section{Abbreviations}

CaOx: calcium oxalate; TCR: T cell receptor; IR-Seq: immune repertoire sequencing; CDR3: complementary determined regions 3; MHC: major histocompatibility complex; APCs: antigen-presenting cells; ROS: reactive oxygen species; IMGT: ImMunoGene Tics information system; HE: haematoxylin and eosin

\section{Acknowledgements \\ Not applicable.}

\section{Authors' contributions}

ZG and KW contributed to the study conception and design; CZ, QL, YL and DK performed the experiments; JZ and HW analyzed the data; KW contributed to manuscript drafting and supervision. All authors read and approved the final manuscript.

\section{Funding}

This work was supported by the National Natural Science Foundation of China (81573759) and the Fundamental Research Funds for the Central Universities (20720190080).

\section{Availability of data and materials}

The datasets supporting the conclusions of this article are included within the article.

\section{Ethics approval and consent to participate}

Human subjects: Not applicable.Animals: All procedures were approved by the Second Military Medical University of the Medicine Institutional Animal Care and Use Committee.

\section{Consent for publication}

Not applicable.

\section{Competing interests}

The authors declare that they have no competing interests.

\section{Author details}

1 Department of Nephrology, Changhai Hospital, Second Military Medical University, Shanghai 200433, China. ${ }^{2}$ Department of Basic Medical Sciences, School of Medicine, Xiamen University, Xiamen 361102, Fujian, China. ${ }^{3}$ Department of Rheumatology and Immunology, Changzheng Hospital, Second Military Medical University, Shanghai 200003, China.

Received: 6 June 2019 Accepted: 13 August 2019

Published online: 22 August 2019

\section{References}

1. Alelign T, Petros B. Kidney stone disease: an update on current concepts. Adv Urol. 2018;2018:3068365.

2. Zeng G, Mai Z, Xia S, Wang Z, Zhang K, Wang L, Long Y, Ma J, Li Y, Wan SP, et al. Prevalence of kidney stones in China: an ultrasonography based cross-sectional study. BJU Int. 2017;120:109-16.

3. Borghi L, Schianchi T, Meschi T, Guerra A, Allegri F, Maggiore U, Novarini A. Comparison of two diets for the prevention of recurrent stones in idiopathic hypercalciuria. N Engl J Med. 2002;346:77-84.

4. Ferraro PM, Taylor EN, Eisner BH, Gambaro G, Rimm EB, Mukamal KJ, Curhan GC. History of kidney stones and the risk of coronary heart disease. JAMA. 2013;310:408-15.

5. Cheungpasitporn W, Thongprayoon C, O'Corragain OA, Edmonds PJ, Ungprasert P, Kittanamongkolchai W, Erickson SB. The risk of kidney cancer in 
patients with kidney stones: a systematic review and meta-analysis. QJM. 2015;108:205-12.

6. Jeong IG, Kang T, Bang JK, Park J, Kim W, Hwang SS, Kim HK, Park HK Association between metabolic syndrome and the presence of kidney stones in a screened population. Am J Kidney Dis. 2011;58:383-8.

7. Edvardsson VO, Goldfarb DS, Lieske JC, Beara-Lasic L, Anglani F, Milliner DS, Palsson R. Hereditary causes of kidney stones and chronic kidney disease. Pediatr Nephrol. 2013;28:1923-42.

8. Vantourout P, Hayday A. Six-of-the-best: unique contributions of gammadelta T cells to immunology. Nat Rev Immunol. 2013;13:88-100.

9. Zou C, Zhao P, Xiao Z, Han X, Fu F, Fu L. Gammadelta T cells in cancer immunotherapy. Oncotarget. 2017;8:8900-9.

10. Fleming C, Morrissey S, Cai Y, Yan J. Gammadelta T cells: unexpected regulators of cancer development and progression. Trends Cancer. 2017;3:561-70.

11. Born WK, Kemal Aydintug M, O'Brien RL. Diversity of gammadelta T-cell antigens. Cell Mol Immunol. 2013;10:13-20.

12. Minculescu $L$, Sengelov $H$. The role of gamma delta $T$ cells in haematopoietic stem cell transplantation. Scand J Immunol. 2015;81:459-68.

13. Kinsey GR, Okusa MD. Expanding role of T cells in acute kidney injury. Curr Opin Nephrol Hypertens. 2014;23:9-16.

14. Khan SR. Reactive oxygen species as the molecular modulators of calcium oxalate kidney stone formation: evidence from clinical and experimental investigations. J Urol. 2013;189:803-11.

15. de Water R, Leenen PJ, Noordermeer C, Nigg AL, Houtsmuller AB, Kok DJ, Schroder FH. Cytokine production induced by binding and processing of calcium oxalate crystals in cultured macrophages. Am J Kidney Dis. 2001;38:331-8.

16. Nazimek K, Filipczak-Bryniarska I, Bryniarski K. The role of medicaments, exosomes and miRNA molecules in modulation of macrophage immune activity. Postepy Hig Med Dosw (Online). 2015;69:1114-29.

17. Tamura M, Aizawa R, Hori M, Ozaki H. Progressive renal dysfunction and macrophage infiltration in interstitial fibrosis in an adenineinduced tubulointerstitial nephritis mouse model. Histochem Cell Biol. 2009;131:483-90.

18. Li D, Hu L, Liang Q, Zhang C, Shi Y, Wang B, Wang K. Peripheral T cell receptor beta immune repertoire is promptly reconstituted after acute myocardial infarction. J Transl Med. 2019;17:40.

19. Liang Q, Liu Z, Zhu C, Wang B, Liu X, Yang Y, Lv X, Mu H, Wang K. Intrahepatic T-cell receptor beta immune repertoire is essential for liver regeneration. Hepatology. 2018;68:1977-90.

20. Okada A, Nomura S, Higashibata Y, Hirose M, Gao B, Yoshimura M, Itoh Y, Yasui T, Tozawa K, Kohri K. Successful formation of calcium oxalate crystal deposition in mouse kidney by intraabdominal glyoxylate injection. Urol Res. 2007;35:89-99.

21. Chen W, Liu WR, Hou JB, Ding JR, Peng ZJ, Gao SY, Dong X, Ma JH, Lin QS, Lu JR, Guo ZY. Metabolomic analysis reveals a protective effect of
Fu-Fang-Jin-Qian-Chao herbal granules on oxalate-induced kidney injury. Biosci Rep. 2019. https://doi.org/10.1042/BSR20181833.

22. Rosenkranz AR, Knight S, Sethi S, Alexander SI, Cotran RS, Mayadas TN. Regulatory interactions of alphabeta and gammadelta T cells in glomerulonephritis. Kidney Int. 2000;58:1055-66.

23. Savransky V, Molls RR, Burne-Taney M, Chien CC, Racusen L, Rabb H. Role of the T-cell receptor in kidney ischemia-reperfusion injury. Kidney Int. 2006;69:233-8.

24. Peng $X$, Xiao Z, Zhang J, Li Y, Dong Y, Du J. IL-17A produced by both gammadelta T and Th17 cells promotes renal fibrosis via RANTES-mediated leukocyte infiltration after renal obstruction. J Pathol. 2015;235:79-89.

25. Kurts C, Heymann F, Lukacs-Kornek V, Boor P, Floege J. Role of T cells and dendritic cells in glomerular immunopathology. Semin Immunopathol. 2007;29:317-35.

26. Chan AJ, Alikhan MA, Odobasic D, Gan PY, Khouri MB, Steinmetz OM, Mansell AS, Kitching AR, Holdsworth SR, Summers SA. Innate IL-17A-producing leukocytes promote acute kidney injury via inflammasome and Toll-like receptor activation. Am J Pathol. 2014;184:1411-8.

27. Turner JE, Krebs C, Tittel AP, Paust HJ, Meyer-Schwesinger C, Bennstein SB, Steinmetz OM, Prinz I, Magnus T, Korn T, et al. IL-17A production by renal gammadelta T cells promotes kidney injury in crescentic GN. J Am Soc Nephrol. 2012;23:1486-95.

28. Davis MM, Bjorkman PJ. T-cell antigen receptor genes and T-cell recognition. Nature. 1988;334:395-402.

29. Brandes M, Willimann K, Moser B. Professional antigen-presentation function by human gammadelta T Cells. Science. 2005;309:264-8.

30. Maryanski JL, Casanova JL, Falk K, Gournier H, Jaulin C, Kourilsky P, Lemonnier FA, Luthy R, Rammensee HG, Rotzschke O, et al. The diversity of antigen-specific TCR repertoires reflects the relative complexity of epitopes recognized. Hum Immunol. 1997;54:117-28.

31. Attaf M, Huseby E, Sewell AK. alphabeta T cell receptors as predictors of health and disease. Cell Mol Immunol. 2015;12:391-9.

32. Boudinot P, Marriotti-Ferrandiz ME, Pasquier LD, Benmansour A, Cazenave PA, Six A. New perspectives for large-scale repertoire analysis of immune receptors. Mol Immunol. 2008:45:2437-45.

33. Liang Q, Liu Z, Zhu C, Wang B, Liu X, Yang Y, Lv X, Mu H, Wang K. Intrahepatic $T$ cell receptor beta immune repertoire is essential for liver regeneration. Hepatology. 2018. https://doi.org/10.1002/hep.30067.

34. Kalyan S, Kabelitz D. Defining the nature of human gammadelta T cells: a biographical sketch of the highly empathetic. Cell Mol Immunol. 2013;10:21-9.

\section{Publisher's Note}

Springer Nature remains neutral with regard to jurisdictional claims in published maps and institutional affiliations.

\footnotetext{
Ready to submit your research? Choose BMC and benefit from:

- fast, convenient online submission

- thorough peer review by experienced researchers in your field

- rapid publication on acceptance

- support for research data, including large and complex data types

- gold Open Access which fosters wider collaboration and increased citations

- maximum visibility for your research: over 100M website views per year
}

At $\mathrm{BMC}$, research is always in progress.

Learn more biomedcentral.com/submissions 